\title{
İskeletsel Sınıf III Bireylerin Çift Çene Ortognatik Cerrahi Sonrası Yumuşak Doku Değişimlerinin Stereofotogrametri ile Değerlendirilmesi
}

\author{
Gökhan Çoban(0000-0001-6066-005X) ${ }^{\alpha}$, İbrahim Yavuz(0000-0001-5760-4858) ${ }^{\alpha}$, Ahmet Emin Demirbaş(0000-0002-2602-6415)
}

Selcuk Dent J, 2021; 8: 721-729 (Doi: 10.15311/selcukdentj.783156)

Başvuru Tarihi: 20 Ağustos 2020

öz

İskeletsel Sınıf III Bireylerin Çift Çene Ortognatik Cerrahi Sonrası Yumuşak Doku Değişimlerinin Stereofotogrametri ile Değerlendirilmesi

Amaç: İskeletsel Sınıf III malokluzyona sahip hastaların, çift çene ortognatik cerrahi tedavi sonrasında yumuşak dokularında meydana gelen değişikliklerin üç boyutlu (3D) fotografik görüntüleme yöntemi ile incelenmesidir.

Gereç ve Yöntemler: Çalışmamız Erciyes Üniversitesi Diş Hekimliği Fakültesi Ortodonti Anabilim Dalı'nda üst çenede tek parçalı Le Fort I, alt çenede bilateral sagital split osteotomisi ile çift cene ortognatik cerrahi tedavisi görmüs 11'i kadın 17'si erkek toplam 28 hasta üzerinde yapılmıştır (yaş ortalaması 20,4 $\pm 3,01$, yaş aralığı 17,03 - 31,16). Ust çene ilerletme miktarı ortalama 4,70 $\pm 1,20 \mathrm{~mm}$ iken; gömme miktarı $2,23 \pm 0,97 \mathrm{~mm}$ 'dir. Alt çene geri alma miktarı ise ortalama 4,23 $\pm 1,56 \mathrm{~mm}$ 'dir. 3D stereofotogrametrik kayıtlar operasyondan hemen önce ve en az 6 ay sonra alınmıştır. Veriler cinsiyetler arasında farklıık gözlenmediği için tek grup olarak değerlendirilmiştir. İstatistiksel analiz için 'paired t testi' kullanıımıștır.

Bulgular: Sagital yönde maksiller uzunluklar, mandibular konveksite açısı, yumuşak doku A ve ANB açıları istatistikse olarak anlamlı şekilde artmıştır. Maksiller konveksite açıSı, mandibular uzunluklar ve korpus uzunlukları, yüz konveksite açısı, total yüz konveksite açısı ve yumuşak doku B açıs istatistiksel olarak anlamlı şekilde azalmıştır. Transvers yönde burun genişliği ve burun tabanı genişliği istatistiksel olarak anlamlı şekilde artmıştır. Vertikal yönde ise maksiller yükseklik, üst vermilyon yüksekliği, orta yüz yüksekliğinin alt yüz yüksekliğine oranı istatistiksel olarak anlamlı şekilde artarken; alt vermilyon yüksekliği, alt dudak uzunluğu, mandibular yükseklik, orta ve alt yüz uzunlukları, ön yüz yüksekliği, vertikal ve mentolabial açılar istatistiksel olarak anlamlı şekilde azalmıştır

Sonuç: Ortognatik cerrahi tedavisi sonucunda en belirgin değişiklikler sagital yönde, en hafif değişiklikler ise transversal yön ölçümlerinde gözlenmiştir. Çalışmamız iskeletsel Sınıf III hastalarda, çift çene ameliyatı sonrası yumuşak doku değișimlerinin ve hasta beklentilerinin ne ölçüde karşılanabileceğinin öngörülebilmesi açısından faydalı olabilir.

\section{ANAHTAR KELIMELER}

İskeletsel Sınıf III, Bimaksiller ortognatik cerrahi, Stereofotogrametri

İskeletsel Sınıf III veya diğer adıyla gerçek mezial okluzyon, alt çenenin hem istirahat halinde hem de kapanış halinde mezial konumda olduğu, genellikle alt ve üst dişler arasında çapraz kapanış durumu gözlenen malokluzyonlardır. ${ }^{1}$ Genellikle kalıtımsal nedenlerle meydana gelmektedir. Yapılan bir fare

\section{ABSTRACT}

Evaluation of Soft Tissue Changes in Skeletal Class III Patients After Bimaxillary Orthognathic Surgery with Stereophotogrammetry

Background: To examine the changes after bimaxillary orthognathic surgery in soft tissues of patients with skeletal Class III malocclusion using three-dimensional (3D) photographic imaging.

Methods: This study was conducted on 28 patients, 11 female, 17 male, who treated with one-piece Le Fort I in the maxilla along with bilateral sagittal split osteotomy in the mandible in Erciyes University Faculty of Dentistry Department of Orthodontics ( mean age $20.4 \pm 3.01$, range $17.03-31.16$ ). While the maxillary advancement amount was $4.70 \pm 1.20 \mathrm{~mm}$; impaction amount was $2.23 \pm 0.97 \mathrm{~mm}$. The amount of mandibular set-back was $4.23 \pm 1.56 \mathrm{~mm}$. 3D stereophotogrammetric recordings were taken just before and at least 6 months after the operation. The data were evaluated as a single group, as no difference was observed between genders. "paired t test" was used for statistical analysis.

Results: In the sagittal direction, maxillary lengths, mandibular convexity angle, soft tissue A and ANB angles increased statistically significantly. The maxillary convexity angle, mandibular lengths and corpus lengths, facial convexity angle, total facial convexity angle and soft tissue B angle were statistically significantly decreased. In the transverse direction, nasal and nasal base widths increased statistically significantly. In the vertical direction, maxillary height, upper vermilion height, the ratio of mid-face height to lower face height increased statistically significantly, lower vermillion height, lower lip length, mandibular height, mid and lower face heights, anterior face height, vertical and mentolabial angles were statistically significantly decreased.

Conclusion: As a result of orthognathic surgery treatment, the most prominent changes were observed in sagittal, the slightest changes in transversal direction measurements. This study may be useful in predicting postoperative soft tissue changes and to what extent patient's expectations can be satisfied in skeletal Class III patients after bimaxillary orthognathic surgery.

\section{KEYWORDS}

Skeletal Class III, bimaxillary orthognathic surgery, Stereophotogrammetry

çalışması 'ªrklı kantitatif özellik lokus'unun (QTLquantitative trait loci) alt çene şeklini belirlediğini göstermiştir. De Nevreze manevrası (alt çenenin zorlanarak geriye doğru itilmesi) başarısızdır. ${ }^{1}$ İskeletsel Sınıf III malokluzyonların tedavisi ve retansiyonu zor olmakla birlikte, tedaviye erken

\footnotetext{
${ }^{\alpha}$ Erciyes Üniversitesi Diş Hekimliği Fakültesi Ortodonti AD, Kayseri, Türkiye

${ }^{\beta}$ Erciyes Üniversitesi Diş Hekimliği Fakültesi Ağız Diş ve Çene Cerrahisi AD, Kayseri, Türkiye
} 
yaşlarda başlanmış olsa bile tedavi süresinin uzun olabileceği; hatta bu sürecin ortognatik cerrahiyle sonuçlanabileceği bildirilmiştir. ${ }^{3}$

Büyüme gelişimini tamamlamış şiddetli iskeletsel uyumsuzluğa sahip hastalarda, yalnızca ortodontik tedavinin kapsamı dışında kalan ağır malokluzyonların ve dentofasiyal şekil bozukluklarının düzeltiminde, ortodonti ile birlikte uygulanan cerrahi prosedürler ortognatik cerrahi olarak tanımlanmıştır. ${ }^{4}$ Proffit, ortodontik problemi büyüme modifikasyonu veya kamuflaj tedavisi ile çözülemeyecek kadar şiddetli olan hastalarda, çenelerin düzgün konumlandırımasında ortognatik cerrahi tedavinin muhtemel tek tedavi seçeneği olduğunu bildirmiştir. ${ }^{5}$

Yüz topografisini inceleyebilmek ve geleneksel iki boyutlu (fotoğraf veya radyografi) yöntemlerinin eksikliklerini karşılayabilmek için birçok üç boyutlu (3D) görüntüleme tekniği kullanılmaktadır. Bu teknikler morfoanaliz, lazer tarama, 3D bilgisayarlı tomografi, stereolitografi, 3D ultrason, 3D fasiyal morfometri, sayısal görüntüleme, Moiré topografisi, kontur (dış hat) fotografisi ve stereofotogrametri olarak bildirilmiştir. Stereofotogrametri, non-invaziv, temassız, görsel tabanlı, 1,5-2 ms'de yüksek kaliteli kayıtlar alabilen, bu kayıtlar üzerinde doğru ve güvenilir ölçümler yapılabilen bir görüntüleme sistemidir. ${ }^{6-8}$

Yumuşak dokuların ameliyat sonrasındaki şekli ve konumu, ortognatik cerrahi tedavinin estetik sonucuna en çok katkıda bulunan unsur olduğundan, yüzdeki yumuşak dokuların ve altında yer alan iskeletsel kaidelerin hareketi arasındaki ilişkiyi anlamak, ortognatik cerrahi tedavinin başarısı açısından son derece önemlidir. ${ }^{9}$ Tedavi planlamasına ait bu 'estetik merkezli' yaklaşımın, ortodontik tedavideki 'okluzyon merkezli' yaklaşımın yerini aldığı bununla birlikte ortognatik cerrahide, dişlerin yüze uyumunun sağlanması gerektiği bildirilmiştir. ${ }^{10}$

Yüzün iskelet yapıları ve üzerini örten yumuşak dokular, hem form hem de fonksiyon açısından birbiriyle ilişkilidir. 'Estetik merkezli' yaklaşımda, alttaki sert dokuların ve konumlarının, yüzün yumuşak doku formunun düzeltilmesine yönelik tedavi taleplerinde ciddi bir etken olduğu; ancak yumuşak doku şeklindeki değişkenliğin \% 50' sinin sert dokulara, diğer \% 50' sinin ise yumuşak dokuya özgü faktörlere bağlı olduğu rapor edilmiştir. ${ }^{11}$ Ayrıca yumuşak doku kalınlıklarının kısa ve uzun yüzlü kişiler arasında farklılık gösterdiği bildirilmiştir. $^{12}$ Masseter kas kalınlığı ve kuvvetinin mandibular düzlem açısı, ön yüz yüksekliği ve yüz genişliği ile ilişkili oldukları raporlanmıştır. ${ }^{13}$

$\mathrm{Bu}$ çalışmanın amacı, iskeletsel Sınıf III anomaliye sahip bireylerde çift çene ortognatik cerrahi tedavi sonucunda meydana gelen yumuşak doku değişikliklerinin 3D fotografik görüntüleme yöntemiyle değerlendirilmesidir.

\section{GEREÇ VE YÖNTEMLER}

Tez çalışmamız Erciyes Üniversitesi Diş Hekimliği Fakültesi Ortodonti Anabilim Dalı'nda Sınıf III çift çene ortognatik cerrahi tedavisi görmüş, yaşları 17,03 ile 31,16 arasında değişen, yaş ortalaması 20,4 43,01 olan, 11'i kadın 17'si erkek toplam 28 hasta üzerinde yapılmıştır (Tablo 1). Buna göre; iskeletsel Sınıf III anomalisi olan ve cerrahi tedavileri çift çene operasyonu ile geçekleştirilmiş erişkin olgulardan alınan üç boyutlu stereofotogrametrik fotoğraflar araştırmamızın materyalini oluşturmuştur. Çalışmamız Erciyes Üniversitesi Klinik Araştırmalar Etik Kurulu tarafından onaylanmıştır (Karar no: 2018/ 83 Tarih: 09.02.2018). G*Power Software version 3.1.9.2 (Universität Düsseldorf, Germany) programı ile yumuşak doku A açısının 9 hastanın 3D kayıtları üzerinden ölçülen verileri kullanılarak yapılan güç analizine göre alfa hata olasılığı 0,05 olan ve \% 95 güç için örneklem boyutunun 26 hastadan oluşması gerektiği tespit edilmiştir.

Çalışmanın dahil edilme kriterleri aşağıdaki gibidir:

- Operasyon öncesine ve tedavi sonuna ait 3D stereofotogrametrik ve radyografik kayıtların tam olması

- Konjenital bir anomali bulunmaması, kraniyofasiyal deformite olmamas

- İskeletsel Sınıf III malokluzyondan kaynaklı, bilateral sagital split osteotomi (BSSO) ile alt çenede geriye alma cerrahisi; üst çenede tek parçalı Le Fort I Osteotomi ile hem total gömme hem de ilerletme hareketinin uygulanmış olduğu çift çene ortognatik cerrahi tedavisi gören hastalar

- Cerrahi operasyonun aynı merkezde (Erciyes Ünv. Diş Hekimliği Fakültesi Ağız Diş Çene Cerrahisi Anabilim Dalı) gerçekleştirilmiş olması

- Cerrahi operasyon sonrasında stabilizasyonunun benzer rijit fiksasyon yöntemleriyle yapılmış olması

- Ortognatik cerrahi yapılmış olan hastaların ameliyat tarihinden itibaren en az 6 ay geçmiş olması

Sınıf III iskeletsel malokluzyonu bulunan ve çift çene ortognatik cerrahi tedavisi gören hastalardan, operasyondan hemen önce ve ameliyat sonrası oluşan ödemin tamamen iyileşebilmesi ve yumuşak dokuların stabilitesinin sağlanabilmesi için ${ }^{14}$ operasyondan en az 6 ay sonra, 3D yüz kayıtları alınmıştır (Tablo 1).

Tablo 1.

Cinsiyetlere göre birey sayısı, yaş ortalaması, yaş aralığı ve ameliyattan sonraki 3dMD kayıtlarının alınma zamanı

\begin{tabular}{|lcccc|}
\hline & Birey sayısı & $\begin{array}{c}\text { Ameliyat Yaş } \\
\text { Ortalaması }\end{array}$ & $\begin{array}{c}\text { Ameliyat Yaş } \\
\text { Aralığı }\end{array}$ & $\begin{array}{c}\text { 3dmd alınma } \\
\text { zamanı }\end{array}$ \\
\hline Erkek & 17 & $19,17 \pm 1,84$ & $17,2-24,70$ & $9,03 \pm 3,31$ \\
\hline Kadın & 11 & $21,64 \pm 3,86$ & $17,03-31,16$ & $10,87 \pm 4,90$ \\
\hline Genel Ortalama & 28 & $20,4 \pm 3,01$ & $17,03-31,16$ & $9,76 \pm 4,02$ \\
\hline
\end{tabular}


3D yüz görüntüleri klinikte ayrı bir odada, standart ışık altında alınmıştır. 3D yüz görüntülerinin elde edilmesi için "3dMD Face" (3dMD TM Ltd, Atlanta, GA, ABD) görüntüleme sistemi kullanılmıştır. Sistem her biri 3 dijital kamera ve bir flaş içeren iki bölümden oluşmaktadır. Görüntüler yüksekliği ayarlanabilir bir sandalye üzerinde, gözlük ve görüntü alanını etkileyecek (örn, piercing) takılar çıkartılmış, çene ucu doğal baş pozisyonundan hafifçe yukarıya yönlendirilmek suretiyle ve gözler açık halde alınmıştır (Resim 1).

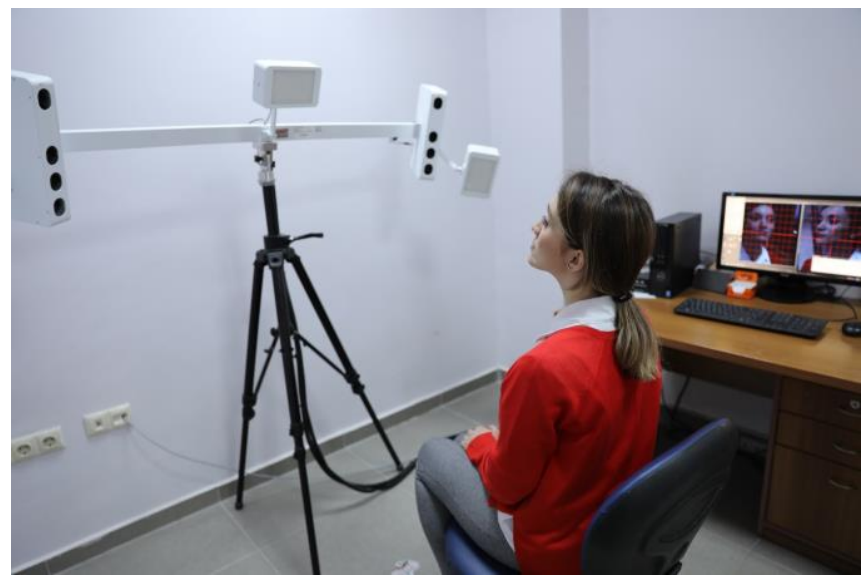

Resim 1

3dMD cihazı ve görüntü kaydı alınma anı

3D görüntüler .tsb formatında kaydedilmiş, görüntülerde istenmeyen bölgelerin çıkarılması, görüntünün uzayda pozisyonlandırıması, çakıştırıması ve ölçüm işlemleri 3dMDvultus (3dMD, Atlanta, GA, $A B D)$ yazılımı kullanılarak yapılmıştır. Görüntünün net olarak oluşmadığı boyun, kulak ve saç bölgeleri görüntüden temizlenmiştir. ${ }^{15}$ Hastaların ortognatik cerrahiden önce ve sonra alınan 3D yüz görüntüleri, alın ve burun kökü ve zigomalar üzerinde ${ }^{16}$, yazılım kılavuzunda belirtilen ve çakıştırma işleminin tutarılı̆̆ını belirleyen RMS (root mean square-ortalama karesel hata) değeri 0,5 ten küçük olacak şekilde ${ }^{17}$ çakıştırılmıştır (Resim 2).

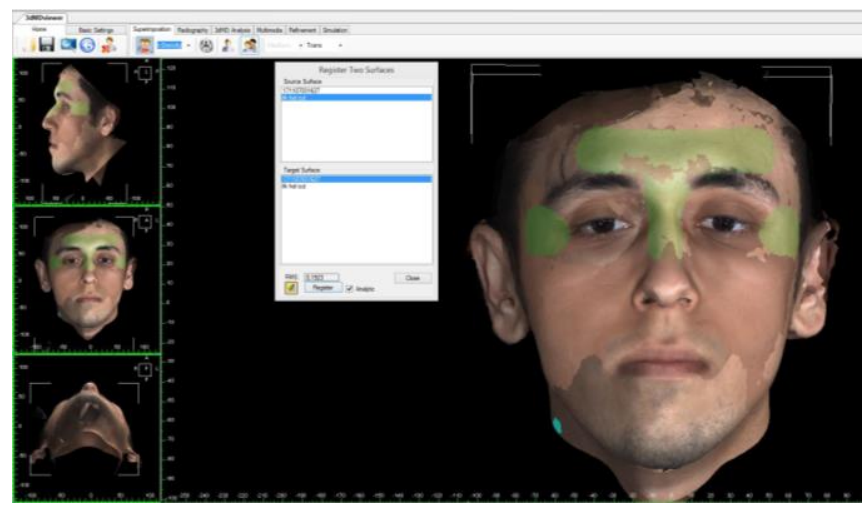

Resim 2

Alnın geniş yüzeyi, burun kökü ve zigomalar bölgesi üzerinde yapılan çakıştırma işlemi
Sagital transversal ve vertikal düzlemlerde çeşitli çizgisel, açısal ve oransal ölçümler ile ortognatik cerrahi tedavi sonrası yumuşak doku değişimleri kaydedilmiştir.

Cerrahi hareket miktarlarının belirlenmesi amacıyla, Dolphin görüntüleme programı (Version 9,0 Dolphin Imaging and Management Solutions, CA, USA) ile Sella - Nasion düzlemine $7^{\circ}$ lik açıyla bir yatay referans düzlemi (Horizontal Reference Plane - HRP) oluşturulmuştur ve bu yatay referans düzlemine yine Sella noktasından dik geçen bir dikey referans düzlemi (Vertical Reference Plane) çizilmiştir. ${ }^{18}$ (Resim 3). Maksilla'nın ortalama ilerletme miktarını hesaplayabilmek için sert doku A noktasının, mandibulanın geri alma miktarını hesaplayabilmek içinse sert doku B noktasının, dikey referans düzlemine uzaklıkları değerlendirilmiş olup; ortalama miktarlar sırasıyla 4,70 $\pm 1,20 \mathrm{~mm}$ ve 4,23 $\pm 1,56$ olarak ölçülmüştür. Maksillanın ortalama gömme miktarı hesaplanmasında, posterior nasal spina (PNS) noktasının yatay referans düzlemine göre uzaklığı değerlendirilmiş olup ortalama miktarı $2.23 \pm 0,97 \mathrm{~mm}$ olarak kaydedilmiştir.

Çalışmamızda kullandığımız antropometrik noktalar ${ }^{19-22}$ ve tanımları Tablo 2'de, yaptığımız ölçümler ise Tablo 3'de verilmiştir. Çift taraflı yer alan noktalar için (en, ex, zyg, cbp, tr, go, al, ac, ch) nokta kısaltmalarının yanına, sağ taraf için 'r' , sol taraf için 'l' harfi konmuştur (Go_r = gonion right, Go_l=gonion left gibi). 
Tablo 2.

\section{Antropometrik yumuşak dokuları ve tanımlamaları}

\begin{tabular}{|c|c|c|}
\hline $\begin{array}{l}\text { Yumuşak doku } \\
\text { noktaları }\end{array}$ & Kısaltmaları & Tanımlaması \\
\hline trichion & $\operatorname{tr}$ & $\begin{array}{l}\text { Alnın ortasından geçen düzlem üzerinde saç } \\
\text { çizgisinin başladığı nokta }\end{array}$ \\
\hline glabella & g & Kaşlar arasındaki en ön orta nokta \\
\hline nasion & $\mathrm{n}$ & $\begin{array}{l}\text { Orta hatta endocanthionları birleştiren doğrunun } \\
\text { üzerinde yer alan, burun kökünün orta noktası }\end{array}$ \\
\hline endocanthion & en & $\begin{array}{l}\text { Üst ve alt göz kapaklarının medialdeki birleşim } \\
\text { noktası }\end{array}$ \\
\hline exocanthion & ex & $\begin{array}{l}\text { Üst ve alt göz kapaklarının lateraldeki birleşim } \\
\text { noktası }\end{array}$ \\
\hline pronasale & prn & $\begin{array}{l}\text { Profilden bakıldığında burun ucunun en ön } \\
\text { noktası }\end{array}$ \\
\hline zygion & zyg & $\begin{array}{l}\text { Yüze cepheden bakııdığında exocanthion } \\
\text { seviyesinde yüzün en dış noktası }\end{array}$ \\
\hline cheek bone point & $\operatorname{cbp}$ & $\begin{array}{l}\text { Kulağın hemen önünden başlayıp burun } \\
\text { tabanına kadar, öne ve aşağıya doğru uzanan } \\
\text { yayın apeksi }\end{array}$ \\
\hline tragion & $\mathrm{t}$ & $\begin{array}{l}\text { Her bir tragusun üst kısmındaki konkavitenin en } \\
\text { derin noktası. Yumuşak doku porion olarak da } \\
\text { kabul edilir. }\end{array}$ \\
\hline gonion & go & $\begin{array}{l}\text { Yüze cepheden bakııdığında mandibula angular } \\
\text { bölgenin en dış noktası }\end{array}$ \\
\hline columella apex & c.a & Her bir nostrilin en üst noktası \\
\hline $\begin{array}{l}\text { columella } \\
\text { constructed point }\end{array}$ & $\mathrm{cc}$ & İki columella apeks noktasının orta noktası \\
\hline alare & al & Burun kanatlarının en dış noktası \\
\hline alare curvature & ac & $\begin{array}{l}\text { Burun kanatlarının üst dudakla birleştiği nokta } \\
\text { veya burun tabanının en dış noktası }\end{array}$ \\
\hline subnasale & sn & $\begin{array}{l}\text { Kolumella tabanı,nasal septum ve üst dudağın } \\
\text { birleştiği en derin orta nokta }\end{array}$ \\
\hline subspinale & ss & Philtrum'un orta hatta en derin noktası \\
\hline cheilion & ch & Ağız köşesi \\
\hline labrale superior & Is & Üst dudağın vermilyon sınırının orta noktası \\
\hline labrale inferior & li & Alt dudağın vermilyon sınırının orta noktası \\
\hline stomion & sto & $\begin{array}{l}\text { Üst ve alt dudakların temas ettikleri orta hattın } \\
\text { orta noktası }\end{array}$ \\
\hline sublabiale & sl & $\begin{array}{l}\text { Alt dudak ile alt çenenin sınııını belirleyen, } \\
\text { profilden bakıldığında labiomental katlantının en } \\
\text { derin noktası }\end{array}$ \\
\hline pogonion & $\mathrm{pg}$ & $\begin{array}{l}\text { Profilden bakıldığında yumuşak doku çene } \\
\text { ucunun orta hatta en ön noktası }\end{array}$ \\
\hline menton & me & Çene ucunun orta hatta en alt noktası \\
\hline
\end{tabular}

Tablo 3.

\section{Sagital, Transversal ve Vertikal Yönde Yapılan Yumuşak Doku Ölçümleri ve Tanımlamaları}

\begin{tabular}{|c|c|}
\hline ÖIçümler & Tanımlaması \\
\hline \multicolumn{2}{|l|}{ Sagital Yön } \\
\hline Maksiller uzunluk (sağ) (T_R - SN), mm & Sağ tragion - subnasale arası uzaklık \\
\hline Maksiller uzunluk (sol) (T_L - SN), mm & Sol tragion - subnasale arası uzaklık \\
\hline Mandibular uzunluk (sağ) (T_R - PG), mm & Sağ tragion - pogonion arası uzaklık \\
\hline Mandibular uzunluk (sol) (T_L - PG), mm & Sol tragion - pogonion arası uzaklık \\
\hline $\begin{array}{l}\text { Mandibular korpus uzunluğu (sağ) } \\
\text { (GO_R-PG), mm }\end{array}$ & Sağ gonion - pogonion arası uzaklık \\
\hline $\begin{array}{l}\text { Mandibular korpus uzunluğu (sol) (GO_L- } \\
\text { PG), mm }\end{array}$ & Sağ gonion - pogonion arası uzaklık \\
\hline $\begin{array}{l}\text { Maksiller konveksite açısı (T_R - SN - } \\
\text { T_L })^{\circ}\end{array}$ & $\begin{array}{l}\text { Sağ tragion - subnasale - sol tragion arası } \\
\text { açı }\end{array}$ \\
\hline $\begin{array}{l}\text { Mandibular konveksite açısı (T_R - PG - } \\
\text { T_L L) }^{\circ}\end{array}$ & $\begin{array}{l}\text { Sağ tragion - pogonion - sol tragion arası } \\
\text { açı }\end{array}$ \\
\hline Yüz konveksite açısı (N-SN -PG) & Nasion - subnasale - pogonion arası açı \\
\hline $\begin{array}{l}\text { Total yüz (Burnun dahil olduğu) } \\
\text { konveksite açısı (N-PRN -PG) }\end{array}$ & Nasion - pronasale - pogonion arası açı \\
\hline Yumuşak doku $\mathrm{A}$ açısı (T_R - N - SS) ${ }^{\circ}$ & $\begin{array}{l}\text { Sağ tragion - nasion - subspinale arası } \\
\text { açı }\end{array}$ \\
\hline Yumuşak doku B açısı (T_R - N - SL) ${ }^{\circ}$ & Sağ tragion - nasion - sublabiale arası açı \\
\hline Yumuşak doku ANB açısı (SS-N-SL) ${ }^{\circ}$ & Subspinale - nasion - sublabiale arası açı \\
\hline \multicolumn{2}{|l|}{ Transversal Yön } \\
\hline Yüz genişliği (T_R - T_L), mm & Sağ tragion - sol tragion arası uzaklık \\
\hline Alt yüz genişliği (GO_R - GO_L), mm & Sağ gonion - sol gonion arası uzaklık \\
\hline Burun genişliği (AL_R - $\left.A L \_L\right), m m$ & Sağ alare - sol alare arası uzaklık \\
\hline Burun tabanı genişliği (AC_R - $A C \_L$ ), mm & $\begin{array}{l}\text { Sağ alar curvature - sol alare curvature } \\
\text { arası uzaklık }\end{array}$ \\
\hline Dudak genişliği (CH_R-CH_L), mm & Sağ cheilion - sol cheilion arası uzaklık \\
\hline \multicolumn{2}{|l|}{ Vertikal Yön } \\
\hline Maksiller yükseklik (SN-STO), mm & Subnasale - stomion arası uzaklık \\
\hline Üst vermilyon yüksekliği (LS_STO), mm & Labrale superior - stomion arası uzaklık \\
\hline Alt vermilyon yüksekliği (STO-LI), mm & Stomion - labrale inferior arası uzaklık \\
\hline Alt dudak uzunluğu (STO-SL), mm & Stomion - sublabiale arası uzaklık \\
\hline Mandibular yükseklik (STO-ME), mm & Stomion - menton arası uzaklık \\
\hline Üst yüz uzunluğu (TR-G), mm & Trichion - glabella arası uzaklık \\
\hline Orta yüz uzunluğu (G-SN), mm & Glabella - subnasale arası uzaklık \\
\hline Alt yüz uzunluğu (SN-ME), mm & Subnasale - menton arası uzaklık \\
\hline $\begin{array}{l}\text { Orta yüzün alt yüze oranı (G_SN } \backslash S N-M E) \\
45 \backslash 5580 \%\end{array}$ & $\begin{array}{l}\text { Glabella -subnasale arası uzaklığın } \\
\text { subnasale - menton arası uzaklığa oranı }\end{array}$ \\
\hline Ön yüz yüksekliği (N-ME), mm & Nasion - menton arası uzaklık \\
\hline Arka yüz yüksekliği (T_R - GO_R), mm & Sağ tragion - sağ gonion arası uzaklık \\
\hline Vertikal açı (N - GO_R - ME) ${ }^{\circ}$ & Nasion- sağ gonion - menton arası açı \\
\hline Mentolabial açı (LI - SL - PG) ${ }^{\circ}$ & $\begin{array}{l}\text { Labrale inferior - sublabiale - pogonion } \\
\text { arası açı }\end{array}$ \\
\hline Nazolabial açı (CC_SN_LS) ${ }^{\circ}$ & $\begin{array}{l}\text { Columella constructed - subnasale - } \\
\text { labrale superior arası açı }\end{array}$ \\
\hline
\end{tabular}




\section{İstatistiksel Analiz}

Çalışmamızda elde edilen veriler istatistiksel olarak SPSS (Social Sciences Software Package for Windows 22, SPSS, Chicago, ABD) programı kullanılarak değerlendirilmiştir. 'Independent $t$ test' ile verilerde cinsiyetler arası farklılık gözlenmediği için veriler tek grup olarak değerlendirilmiştir. 'Shapiro-Wilk testi'ne tabi tutulan verilerin normal dağılım gösterdiği tespit edilmiş olup, tedavi öncesi ve sonrasındaki verilerin analizi için 'paired t testi' kullanılmıştır. Bulguların istatistiksel olarak anlamlı kabul edileceği düzey $\mathrm{p} \leq 0,05$ olarak belirlenmiştir.

\section{BULGULAR}

\section{Yöntem Hatasının Değerlendirilmesi}

Araştırmacının tutarlılı̆ının hesaplanabilmesi için 10 hastanın cerrahi öncesi ve sonrası üç boyutlu fotoğraf ölçümleri 1 hafta sonra tekrarlanmıştır. Yöntem hatasının hesaplanmasında Dahlberg formülü $\left(\sqrt{\Sigma} \mathrm{d}^{2} / 2 n\right)$ kullanılmıştır.

$d=$ Birinci ve ikinci ölçüm arasındaki fark

$\mathrm{n}=$ Tekrar ölçüm yapılan denek sayısı

Dahlberg formülü ile edilen sonuçların istatistiksel olarak anlamlı olmadığı tespit edilmiştir.

\section{Sagital Ölçümler}

Sağ ve sol maksiller uzunluklar, mandibular konveksite açısı, yumuşak doku A açısı ve ANB açısı istatistiksel olarak anlamlı şekilde artmışıı (Tablo 4). Maksiller konveksite açısı, sağ ve sol mandibular uzunluklar, sağ ve sol mandibular korpus uzunlukları, yüz konveksite açısı, burnun dahil olduğu total yüz konveksite açısı ve yumuşak doku B açısı istatistiksel olarak anlamlı şekilde azalmıştır (Tablo 4).

Tablo 4.

\section{Sagital Ölçümler}

\begin{tabular}{|c|c|c|c|c|c|}
\hline \multirow{2}{*}{ Ölçümler } & \multicolumn{2}{|c|}{ Tо } & \multicolumn{2}{|c|}{ T1 } & \multirow{2}{*}{$\mathbf{p}$} \\
\hline & Ort. & ss. & Ort. & ss. & \\
\hline Maksiller uzunluk (sağ) & 123,38 & 6,2 & 125,79 & 6,44 & *** \\
\hline Maksiller uzunluk (sol) & 121,96 & 5,77 & 124 & 5,81 & *** \\
\hline Maksiller konveksite açısı & 73,15 & 2,77 & 72,22 & 2,88 & *** \\
\hline Mandibular uzunluk (sağ) & 143,9 & 7,1 & 141,81 & 7,39 & 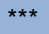 \\
\hline Mandibular uzunluk (sol) & 143,43 & 6,74 & 141,35 & 7,14 & *** \\
\hline Mandibular konveksite açısı & 61,14 & 1,86 & 62,64 & 2,25 & *** \\
\hline $\begin{array}{l}\text { Mandibular korpus uzunluğu } \\
\text { (sağ) }\end{array}$ & 102,11 & 8,42 & 100,2 & 8,76 & ** \\
\hline Mandibular korpus uzunluğu (sol) & 102,2 & 6,4 & 100,8 & 7,03 & ** \\
\hline Yüz konveksite açısı & 171,8 & 4,69 & 166,35 & 5,6 & *** \\
\hline Total yüz konveksite açısı & 138,1 & 4,89 & 133,15 & 4,27 & *** \\
\hline Yumuşak doku $A$ açısı & 78,76 & 3,26 & 82,25 & 3,52 & *** \\
\hline Yumuşak doku B açısı & 77,56 & 2,93 & 76,34 & 2,99 & 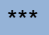 \\
\hline Yumuşak doku ANB açısı & 1,2 & 2,03 & 5,9 & 1,67 & *** \\
\hline
\end{tabular}

\section{Transversal Ölçümler}

Burun genişliği ve burun tabanı genişliği istatistiksel olarak anlamlı şekilde artarken; yüz genişliği, alt yüz genişliği ve dudak genişliklerinde istatistiksel olarak anlamlı bir değişiklik izlenmemiştir (Tablo 5).

Tablo 5.

\section{Transversal Ölçümler}

\begin{tabular}{|c|c|c|c|c|c|}
\hline \multirow{2}{*}{ Ölçümler } & \multicolumn{2}{|c|}{ то } & \multicolumn{2}{|c|}{ T1 } & \multirow{2}{*}{$\mathbf{p}$} \\
\hline & Ort. & ss. & Ort. & ss. & \\
\hline Yüz genişliği & 146,13 & 7,31 & 146,52 & 7,4 & \\
\hline Alt yüz genişliği & 109,35 & 10,06 & 108,64 & 10,14 & \\
\hline Burun genişliği & 35,86 & 3,39 & 38,36 & 3,49 & *** \\
\hline Burun tabanı genişliği & 30,17 & 2,76 & 33,52 & 3,14 & *** \\
\hline Dudak genisliği & 51,46 & 3,91 & 51,86 & 4,24 & \\
\hline
\end{tabular}

$* p<.005 ; * * p<.01 ; * * * p<.001$.

TO: Ameliyat öncesi; T1: Ameliyat sonrası, Ort: Ortalama değer; Ss: Standart sapma

\section{Vertikal Ölçümler}

Maksiller yükseklik, üst vermilyon yüksekliği, orta yüz yüksekliğinin alt yüz yüksekliğine oranı istatistiksel olarak anlamlı şekilde artarken; alt vermilyon yüksekliği, alt dudak uzunluğu, mandibular yükseklik, orta ve alt yüz uzunlukları, ön yüz yüksekliği, vertikal ve mentolabial açılar istatistiksel olarak anlamlı şekilde azalmıştır (Tablo 6). Üst yüz yüksekliğinde, arka yüz yüksekliğinde ve nazolabial açıda ise istatistiksel olarak anlamlı bir değişiklik izlenmemiştir (Tablo 6)

Tablo 6

\section{Vertikal Ölçümler}

\begin{tabular}{|c|c|c|c|c|c|}
\hline \multirow[t]{2}{*}{ Ölçümler } & \multicolumn{2}{|l|}{ TO } & \multicolumn{2}{|l|}{ T1 } & \multirow[t]{2}{*}{$\mathbf{p}$} \\
\hline & Ort. & ss. & Ort. & ss. & \\
\hline Maksiller yükseklik & 20,26 & 3,76 & 21,43 & 2,79 & ** \\
\hline Üst vermilyon yüksekliği & 5,65 & 1,41 & 7,46 & 1,24 & *** \\
\hline Alt vermilyon yüksekliği & 8,28 & 1,64 & 6,6 & 1,49 & *** \\
\hline Alt dudak uzunluğu & 22,05 & 2,69 & 18,69 & 2,69 & *** \\
\hline Mandibular yükseklik & 52,02 & 4,52 & 48,65 & 4,38 & *** \\
\hline Üst yüz uzunluğu & 41,96 & 10,97 & 42 & 10,98 & \\
\hline Orta yüz uzunluğu & 72,05 & 5,34 & 71,72 & 5,15 & * \\
\hline Alt yüz uzunluğu & 71,84 & 7,23 & 69,54 & 6,02 & *** \\
\hline Orta yüz / alt yüz oranı & 1,01 & 0,1 & 1,03 & 0,08 & * \\
\hline Ön yüz yüksekliği & 124,01 & 9,07 & 120,45 & 8,01 & *** \\
\hline Arka yüz yüksekliği & 56,61 & 6,03 & 56,86 & 6,18 & \\
\hline Vertikal açı & 66,37 & 4,55 & 64,68 & 3,53 & *** \\
\hline Mentolabial açı & 158,18 & 12,33 & 141,51 & 10,71 & *** \\
\hline Nazolabial açı & 99,77 & 14,36 & 100,29 & 9,79 & \\
\hline
\end{tabular}

TO: Ameliyat öncesi; T1: Ameliyat sonrası, Ort: Ortalama değer; Ss: Standart sapma 


\section{TARTIŞMA}

Bu çalışmanın amacı çift çene ortognatik cerrahi tedavisi görmüş iskeletsel Sınıf III hastaların ameliyat sonrasında, yüz yumuşak dokularında meydana gelen değişikliklerin 3D stereofotogrametrik yöntemle incelenmesidir.

Stereofotogrametri, Yunanca'da stereos (katı), photos (Işık), grama (çizim) ve metron (ölçüm) kelimelerinin birleşiminden oluşmaktadır. ${ }^{23}$ Stereofotogrametri tekniğinde, görüntüsü alınacak nesneden eşit uzaklıkta ve aynı hat üzerinde yer alan birbiriyle uyumlandırılmış en az iki kameradan elde edilen görüntülerin bir bilgisayar programı aracılığıyla birleştirilmesi neticesinde 3D görüntüler elde edilmektedir. Tekniğin avantajları, herhangi bir radyasyona veya invaziv bir işleme gerek olmaksızın yüzün detaylıca değerlendirilebilmesi, 1,5-2 ms'de yüksek kaliteli 3D görüntü elde edilmesi, bu görüntüler üzerinde 0,2 mm'lik hata payı ile oldukça güvenilir ölçümler yapılabilmesi ${ }^{24,25}$, tekrarlanabilirliğinin yüksek olması, doğrusal ölçümlerin yanı sıra topografik, alansal ve hacimsel ölçümler de yapılabilmesi, tedavi öncesi ve sonrası çakıştırma işlemi yapılabilmesi, kayıtların depolanması, ölçümlerin farklı dosya uzantıları ile diğer programlarda kullanılmak üzere dışa aktarılabilmesi ve tedavi sonuçlarının değerlendirilebilmesidir. ${ }^{23,26}$ Sert dokuların incelenmesi için ilave görüntüleme yöntemlerine (KIBT gibi) intiyaç duyulması, sistemin çok pahalı olması ve tesisatı için geniş bir alana ihtiyaç duyulması, karmaşık alanlar ve anatomik boşlukların görüntülenmesindeki başarısızlıklar, sistemin sık aralıklarla kalibre edilme gereksinimi, dinamik görüntü alınamaması ise dezavantajları olarak sıralanmaktadır. ${ }^{23}$

Yüz konveksitesinin, yüz cazibesinde önemli bir faktör olduğu bu nedenle, yüz hatları konkav olan iskeletsel Sınıf III hastalarda konveks profilin hedeflenmesi gerektiği bildirilmiştir. ${ }^{27,28}$ Sforza $^{29}$ ortognatik cerrahi ameliyatından sonra maksiller belirginliğin artması ile birlikte çalışmamızdakine benzer şekilde, yüz konveksite açısı ve burnun dâhil olduğu total yüz konveksite açısının azaldığını yani profilin belirgin derecede konveks hale geldiğini bildirmiştir.

Ferrario, özellikle yüz konveksitesi ve yumuşak doku ANB açısının, ameliyat öncesinde, referans normlardan önemli ölçüde farklı olduğunu ve ameliyattan sonra yüzün orta üçlüsünün cerrahi olarak ilerletilmesi, yüzün alt üçlüsünün ise geri alınması ile düzeldiğini rapor etmiştir. ${ }^{30}$ Maksiller ilerletme ile neticesinde subnasale noktasının ileri taşınması sebebi ile sağ ve sol maksiller uzunluklarında artış, maksiller konveksite açısında azalma, mandibular geri alma neticesinde pogonion noktasının geriye taşınması sebebi ile sağ ve sol mandibular uzunlukta ve mandibular gövde uzunluklarında ve mandibular açıda azalmalar görülmüştür.
Kochel 2009 'da, 100 hasta üzerinde 3 boyutlu sagital normları belirlemek için yaptığı çalışmada, yumuşak doku A açısının değerini $76,01^{\circ} \pm 2,98^{\circ}$, yumuşak doku B açısının değerini ise $69,64^{\circ} \pm 3,03^{\circ}$ olarak rapor etmiştir. ${ }^{31}$ Bizim çalışmamızda ise bu değerler ameliyat öncesinde sırasıyla $78,76^{\circ} \pm 3,26^{\circ}$ ve $77,56^{\circ} \pm 2,93^{\circ}$ iken; ameliyat sonrasında sırasıyla $82.25^{\circ} \pm 3.52^{\circ}$, $76,34^{\circ} \pm 2,99^{\circ}$ olarak bulunmuştur. İlgili ölçümlerdeki farklııklar ırksal değişikliklerden ve yumuşak doku kalınlıklarından kaynaklanabilir. Yumuşak doku ANB açısı ise $1,20^{\circ} \pm 2,03^{\circ}$ den, $5,90^{\circ} \pm 1,67^{\circ}$ ye yükselmiştir. Yumuşak doku ANB açısının ameliyat öncesindeki ortalamasının pozitif olması dikkat çekicidir.

Yakın zamanda yapılan bir araştırma, burun genişliğinde meydana gelen artışın, hastaların \% 80' inden fazlasında maksiller ilerletme mesafesinin yaklaşık yarısına karşılık geldiğini göstermiştir. ${ }^{32,33}$ Baik ve ark.'nın yaptığı çalışmada, çalışmamızdakine benzer şekilde burun kanatları arası genişlikte istatistiksel olarak anlamlı $2 \mathrm{~mm}$ artış görülürken; yüz genişliğinde ve cheilionlar arası dudak genişliğinde istatistiksel olarak anlamlı bir farklılık saptanmamıştır. ${ }^{34}$

Choi ve ark.'nın maksiller ilerletme olmaksızın maksilla posteriorda gömme ve mandibular set back yaptığı 25 iskeletsel Sınıf III hastasında 3D kamera ile yaptığı çalışmada, ameliyat sonrası ortalama bigonial genişlik istatistiksel olarak anlamlı bir şekilde 113,5 mm'den 109,2 mm'ye düşmekte ve araştırmacı bu durumu maksilladaki posterior gömmenin, mandibulanın geri alınırken saat yönünde rotasyonuna sebebiyet vermesi ile açıklamaktadır. ${ }^{35}$ Sforza ve ark.'। 7 kadın 2 erkek toplam 9 hastada yaptığı çalışmanın sonuçlarına göre kadınlarda alt yüz genişliğinin azaldığını bildirmiştir. ${ }^{29}$ Çalışmamızda alt yüz genişliğinde (bigonial mesafe) istatistiksel olarak anlamlı bir değişiklik olmazken, Baik'in çalışmasında istatistiksel olarak anlamlı bir artış meydana gelmiştir. ${ }^{34}$ Choi ve ark.'ı maksillayı saat yönünde rotasyona uğrattıkları Sınıf III cerrahi hastalarında alt yüz genişliğinin ortalama $3.21 \mathrm{~mm}$ arttığını alt yüz yüksekliğinin ise azaldığını rapor etmişler ve bu şekilde hastaların ortognatik cerrahiden sonra değişen profil görünümlerinden memnun olsalar bile cephe görünümlerinde genişleyen bir alt yüz ile tatmin olmayabileceklerini bildirmişlerdir. ${ }^{36}$ Alt yüz genişliğine ait farklılık, örneklem gruplarındaki sayıların, cerrahi tekniğin ve 3D değerlendirme yöntemlerinin farklı olmasından kaynaklanabilir.

Choi ve ark'ı üst vermilyon uzunluğunda $0.2 \mathrm{~mm}$, alt vermilyon uzunluğunda ise $0,4 \mathrm{~mm}$ azalma bildirmiştir. ${ }^{35}$ Yüzün üst üçlüsünün uzunluğunda bir değişiklik görmediklerini ve orta üçlüsünü uzunluğunun ise yalnızca $1 \mathrm{~mm}$ azaldığını, bunun da maksillayı saat yönünde döndürmek için posterior gömme işlemi uygulanması sonucu olduğunu belirtmiştir. Buna karşın, yüzün alt üçlüsünün uzunluğu 70,4 mm'den 68,2 mm'ye önemli ölçüde azalmıştır. 
Maksiller yüksekliğin 22,7 mm'den 23,7 mm'ye arttığı, mandibular yüksekliğin ise 47,9 mm'den 44,2 mm'ye anlamlı derecede azaldığı bildirilmiştir. ${ }^{35}$ Choi ve ark.'nın çalışmasında bahsedilen tüm vertikal bulgulardaki değişiklikler bizim çalışmamızdakine benzer şekildedir.

Baik ve ark.'ı çalışmamızdakine benzer şekilde ön yüz yüksekliğinde ortalama $5 \mathrm{~mm}$ azalma bildirmiştir; ancak çalışmamızdakinin aksine arka yüz yüksekliğinde (mandibular ramus yüksekliği) ortalama $7 \mathrm{~mm}$ azalma rapor etmiştir. ${ }^{34} \mathrm{Bu}$ farkın gömme miktarlarının farklı olması ve alt çenedeki cerrahi tekniğin bahsedilen çalışmada intraoral vertikal ramus osteotomisi olması düşünülmektedir. Aynı çalışmada yüzün orta üçlüsünün uzunluğu değişmezken, yüzün alt üçlüsünün uzunluğunda anlamlı bir azalma, orta üçlünün alt üçlüye oranında ise anlamlı bir artış bildirilmiştir. Baik maksiller uzunlukta (üst dudak uzunluğu) anlamlı bir artış, mandibular uzunlukta ise anlamlı bir azalma görüldüğünü bildirmiştir. ${ }^{34}$

Kochel ve ark.'ı, 100 hastada 3D vertikal normları belirlemek için yaptığı çalışmada, vertikal açının değerini $71,50^{\circ} \pm 4,00^{\circ}$ olarak rapor etmiştir. ${ }^{37}$ Bizim çalışmamızda ise bu değerler ameliyat öncesinde $66,37^{\circ} \pm 4,55^{\circ}$ iken; ameliyat sonrasında maksiller gömmeye bağlı olarak $64,68^{\circ} \pm 3,53^{\circ}$ olarak bulunmuştur.

Jensen ve ark.'ı 1992 de maksiller gömme ile birlikte ilerletme ve mandibular ilerletme cerrahisi yapılan 17 hastada üst çenenin ortalama $3,4 \mathrm{~mm}$ gömülmesi ve 1,8 mm öne alınması ile maksiller uzunlukta bizim çalışmamızdakinin aksine ortalama 0,8 mm'lik kısalma bildirmiştir. ${ }^{38}$ Bizim çalışmamızdaki ilerletme miktarı 4,7 mm iken gömme miktarı 2,2 mm'dir. Aynı çalışmada, nazolabial açının maksillanın aşağı ve geriye rotasyon yaptırıldığı olgularda $5,6^{\circ}$ azaldığı, yukarıya ve öne rotasyon yaptırıldığı vakalarda ortalama $6,5^{\circ}$ arttığı, genel olarak, her $1 \mathrm{~mm}$ 'lik maksiller ilerletme için nazolabial açıda $0,65^{\circ}$ lik bir artış olduğu rapor edilmiştir. Nazolabial açıdaki değişikliklerin altta yatan sert dokuların ön-arka ve dikey hareketlerinden ziyade öncelikle rotasyonel hareketine bağlı olduğu rapor edilmiştir. ${ }^{38} \mathrm{Da}$ Silva ve ark.'nın yaptığı çalışmada, ameliyattan 1 yıl sonra üst dudak yüksekliği postoperatif dönemde çalışmamızdakine benzer şekilde ortalama $0,9 \mathrm{~mm}$ artış göstermiştir. ${ }^{33}$ Kale ve ark.'nın 2008 de 111 iskeletsel Sınıf I Anadolu insanının fotoğrafları üzerinde yaptığı çalışmanın sonuçlarına göre mentolabial açının ortalama değeri $125,9^{\circ} \pm 4,24^{\circ}$ ${ }^{39}$, Arnett ve McLaughlin'e göre ise $130^{\circ}$ ve hafifçe üzeri olarak rapor edilmiştir. ${ }^{40}$ Bizim çalışmamızda da ameliyat öncesi $158,18^{\circ} \pm 12,33^{\circ}$ olan mentolabial açı değeri ameliyat sonrasında Türk normlarına daha yakın olan $141,51^{\circ} \pm 10,71^{\circ}$ değerlerine inmiştir.

Hemmatpour ve ark.'nın 2016 da ortalama 4 mm maksiller ilerletme $7 \mathrm{~mm}$ mandibular geri alma cerrahisi uygulanan 20 İranlı hastada 2 boyutlu fotoğraflar üzerinde yaptığı çalışmaya göre, bizim çalışmamızdakine benzer şekilde alt dudak uzunluğunda istatistiksel olarak anlamlı bir azalma bildirmiştir. ${ }^{41} \mathrm{Kim}$ ve ark. ise alt yüz yüksekliğinin, mandibulanın yukarı ve geri hareketi nedeniyle önemli ölçüde azaldığını rapor etmişlerdir. ${ }^{42}$ Alt yüz uzunluğundaki azalmanın, alt vermilyon uzunluğundaki azalmadan fazla olması ameliyat öncesi ve sonrası interlabial boşluktaki farklılıklardan kaynaklanıyor olabilir. ${ }^{42}$

Ortognatik cerrahinin, yumuşak dokuların şeklinde ve konumunda önemli değişikliklere neden olabileceği, bu değişikliklerin sadece yüzün yumuşak dokuları ile sınırlı olmadığı, aynı zamanda havayolunu şekillendiren yumuşak dokuları da kapsadığı, yumuşak dokuların, altında yatan sert dokulardaki değişikliklere nasıl tepki verdiğine ilişkin, bireysel değişkenliklerden kaynaklı, kesin bir öngörü yapılamayacağı rapor edilmiştir. ${ }^{9}$ Hasta tarafından ortognatik cerrahi sonucunun başarılı olarak değerlendirilmesinde, postoperatif yumuşak doku profilinin kuvvetli bir etken olduğu bildirmiştir. ${ }^{15} \mathrm{Bu}$ yüzden herhangi bir ortognatik vakanın cerrahi öncesi incelemesinde hem ortodontist hem de çene cerrahının başlıca endişelerinden biri, hastanın tedavinin bitimindeki yumuşak doku profili ve estetik görünümü olmalıdır. Burun, dudak ve çenenin ön-arka yöndeki pozisyonları, yumuşak dokuların miktarı, oranları ve konturları ameliyat sonrasında optimum profil elde etmek için dikatlice değerlendirilmelidir. ${ }^{35}$

\section{SONUC}

3D fotoğrafik görüntüleme yöntemi kullanarak incelediğimiz, üst çenede gömme ve ilerletme ile birlikte alt çenede geri alma cerrahisi uygulanmış toplam 28 hasta ile yaptığımız çalışmamızda elde ettiğimiz sonuçlar aşağıda sıralanmıştır:

- Yumuşak dokularda meydana gelen değişimler sagital > vertikal > transversal yönde izlenmiştir.

- Sagital yönde yumuşak doku A açısı, ANB açısı ve maksiller uzunluk artarken; yüz ve total yüz konveksite açıları, mandibular uzunluk, korpus uzunluğu ve yumuşak doku B açısı azalmıştır.

- Transvers yönde yalnızca burun kanadı ve tabanı genişliklerinde artış gözlenmiştir.

- Vertikal yönde, maksiller yükseklik, üst vermilyon uzunluğu ve ort yüzün alt yüze oranı artarken; mandibular yükseklik, alt dudak, alt vermilyon, ön yüz, orta yüz, alt yüz yükseklikleri ile mentolabial ve vertikal açı azalmıştır. 


\section{KAYNAKLAR}

1. Alami S, Aghoutan H, El Quars F, Diouny S, Bourzgui F. Early Treatment of Anterior Crossbite Relating to Functional Class III. Emerging Trends in Oral Health Sciences and Dentistry: InTech; 2015. p. 341-363.

2. Klingenberg CP, Leamy LJ, Cheverud JM. Integration and modularity of quantitative trait locus effects on geometric shape in the mouse mandible. Genetics 2004;166:1909-21.

3. Bishara SE. Chapter 21: Treatment of Class III Malocclusion in the Primary and Mixed Dentitions. Textbook of orthodontics. WB Saunders; 2001. p. 375415.

4. Wolford L, Fields R. Diagnosis and treatment planning for orthognathic surgery. Oral Maxillofac Surg 2000;2:24-55.

5. Proffit WR, Fields Jr HW, Sarver DM. Ch 19.Combined Surgical and Orthodontic Treatment. Contemporary of Orthodontics, 4th Ed. Elsevier Health Sciences; 2006. p. 686-718.

6. Hajeer MY, Ayoub AF, Millett DT, Bock M, Siebert J. Three-dimensional imaging in orthognathic surgery: the clinical application of a new method. Int J Adult Orthodon Orthognath Surg. 2001;17:318-30.

7. Wermker K, Kleinheinz J, Jung S, Dirksen D. Soft tissue response and facial symmetry after orthognathic surgery. J Craniomaxillofac Surg. 2014;42:e339-e45.

8. Öztürk T, Gül Amuk N. Three-dimensional evaluation of soft tissue changes after fixed palatal crib application in anterior open-bite cases. Yeditepe J Dent. 2019;15:2917.

9. Naini FB, Gill DS. Chapter 16: The Soft Tissue Effects of Orthognathic Surgery. Orthognathic Surgery: Principles, Planning And Practice. John Wiley \& Sons; 2017. p. 3417.

10.Naini FB, Cobourne MT, McDonald F, Wertheim D. The aesthetic impact of upper lip inclination in orthodontics and orthognathic surgery. Eur J Orthod. 2014;37:81-6.

11. Halazonetis DJ. Morphometric correlation between facial soft-tissue profile shape and skeletal pattern in children and adolescents. Am J Orthod Dentofacial Orthop. 2007;132:450-7.

12. Blanchette ME, Nanda RS, Currier GF, Ghosh J, Nanda SK. A longitudinal cephalometric study of the soft tissue profile of short-and long face syndromes from 7 to 17 years. Am J Orthod Dentofacial Orthop. 1996;109:11631.

13. Kubota M, Nakano H, Sanjo I, Satoh K, Sanjo T, Kamegai $\mathrm{T}$, et al. Maxillofacial morphology and masseter muscle thickness in adults. Eur J Orthod. 1998;20:535-42.

14.Sarver DM, Weissman SM. Long-term soft tissue response to LeFort I maxillary superior repositioning. Angle Orthod. 1991;61:267-76.

15. Baysal A, Ozturk MA, Sahan AO, Uysal T. Facial softtissue changes after rapid maxillary expansion analyzed with 3-dimensional stereophotogrammetry: A randomized, controlled clinical trial. Angle Orthod. 2016;86:934-42.
16.Verhoeven T, Coppen C, Barkhuysen $R$, Bronkhorst E, Merkx M, Bergé S, et al. Three dimensional evaluation of facial asymmetry after mandibular reconstruction: validation of a new method using stereophotogrammetry.Int $\mathrm{J}$ Oral Maxillofac Surg. 2013;42:19-25.

17. Lin H-H, Chiang W-C, Lo L-J, Hsu SS-P, Wang C$\mathrm{H}$, Wan S-Y. Artifact-resistant superimposition of digital dental models and cone-beam computed tomography images. J Oral Maxillofac Surg. 2013;71:1933-47.

18.Park J-Y, Kim MJ, Hwang SJ. Soft tissue profile changes after setback genioplasty in orthognathic surgery patients. J Craniomaxillofac Surg. 2013;41:657-64.

19.Plooij J, Swennen G, Rangel F, Maal T, Schutyser $F$, Bronkhorst $E$, et al. Evaluation of reproducibility and reliability of 3D soft tissue analysis using 3D stereophotogrammetry. Int J Oral Maxillofac Surg. 2009;38:267-73.

20.Farkas LG. Anthropometry of the Head and Face: Raven Pr; 1994.

21.Bishara SE, Cummins DM, Jorgensen GJ, Jakobsen JR. A computer assisted photogrammetric analysis of soft tissue changes after orthodontic treatment. Part I: methodology and reliability. Am J Orthod Dentofacial Orthop. 1995;107:633-9.

22. Chung C, Lee Y, Park K-H, Park S-H, Park Y-C, Kim $\mathrm{K}-\mathrm{H}$. Nasal changes after surgical correction of skeletal Class III malocclusion in Koreans. Angle Orthod. 2008;78:427-32.

23.Özdiler E. Bölüm 16. Üç Boyutlu Stereofotogrametri. Güncel Bilgiler Işığında Ortodonti. 2015:367-78.

24.Lübbers H-T, Medinger L, Kruse A, Grätz KW, Matthews F. Precision and accuracy of the $3 \mathrm{dMD}$ photogrammetric system in craniomaxillofacial application. J Craniofac Surg. 2010;21:763-7.

25. Metzler $P$, Sun $Y$, Zemann W, Bartella A, Lehner M, Obwegeser JA, et al. Validity of the 3D VECTRA photogrammetric surface imaging system for cranio-maxillofacial anthropometric measurements. Oral Maxillofac Surg. 2014;18:297-304.

26. Amuk NG, Topsakal KG, Keklikci HB. Effects of Different Head Positioning Methods on Facial Soft Tissue Analysis Using Stereophotogrammetry. Journal of Oral and Maxillofacial Surgery. 2019;77:1277. e1-. e10.

27. Alves PVM, Zhao L, Patel PK, Bolognese AM. Three-dimensional facial surface analysis of patients with skeletal malocclusion. J Craniofac Surg. 2009;20:290-6.

28.Patel PK, Novia MV. The surgical tools: the LeFort I, bilateral sagittal split osteotomy of the mandible, and the osseous genioplasty. Clin Plast Surg. 2007;34:447-75. 
29.Sforza C, Peretta R, Grandi G, Ferronato G, Ferrario VF. Three-dimensional facial morphometry in skeletal Class III patients: A non-invasive study of soft-tissue changes before and after orthognathic surgery. $\mathrm{Br} J$ Oral Maxillofac Surg. 2007;45:138-44.

30.Ferrario VF, Sforza C, Schmitz JH, Santoro F. Threedimensional facial morphometric assessment of soft tissue changes after orthognathic surgery. Oral Surg Oral Med Oral Pathol Oral Radiol Endod. 1999;88:549-56.

31. Kochel J, Meyer-Marcotty P, Strnad F, Kochel M, StellzigEisenhauer A. 3D Soft tissue analysis-Part 1: Sagittal parameters. J Orofac Orthop. 2010;71:40-52.

32. Hellak AF, Kirsten B, Schauseil M, Davids R, Kater WM, Korbmacher-Steiner HM. Influence of maxillary advancement surgery on skeletal and soft-tissue changes in the nose-a retrospective cone-beam computed tomography study. Head Face Med 2015;11:23.

33.da Silva AMBR, Magri LV, Osborne PR, Trivelatto AE, Sverzut CE, da Silva MAMR. Three-Dimensional nasal alterations in Le Fort I advancement: linear measurements, angles, nasal indices, and volume differences. J Craniofac Surg. 2019;30:1125-30.

34. Baik H-S, Kim S-Y. Facial soft-tissue changes in skeletal Class III orthognathic surgery patients analyzed with 3dimensional laser scanning. Am J Orthod Dentofacial Orthop. 2010;138:167-78.

35. Choi JW, Lee JY, Oh T-S, Kwon SM, Yang SJ, Koh KS. Frontal soft tissue analysis using a 3 dimensional camera following two-jaw rotational orthognathic surgery in skeletal class III patients. J Craniomaxillofac Surg. 2014;42:220-6.

36. Choi T-H, Kim S-H, Yun P-Y, Kim Y-K, Lee N-K. Soft Tissue Changes After Clockwise Rotation of Maxillomandibular Complex in Class III Patients: ThreeDimensional Stereophotogrammetric Evaluation. J Craniofac Surg. 2020. DOI: $10.1097 /$ SCS.0000000000006877.

37.Kochel J, Meyer-Marcotty P, Kochel M, Schneck S, Stellzig-Eisenhauer A. 3D Soft Tissue Analysis-Part 2: Vertical Parameters. J Orofac Orthop. 2010;71:207-20.

38. Jensen AC, Sinclair PM, Wolford LM. Soft tissue changes associated with double jaw surgery. Am J Orthod Dentofacial Orthop. 1992;101:266-75.

39. Kale-Varlık S. Angular photogrammetric analysis of the soft tissue facial profile of Anatolian Turkish adults. J Craniofac Surg. 2008;19:1481-6.

40.Arnett G, Mc Laughlin R. Facial and dental planning for orthodontists and oral surgeons. 2004, St. Louis: Mosby. p. 162.

41. Hemmatpour S, Oliadarani FK, Hasani A, Rakhshan V. Frontal-view nasolabial soft tissue alterations after bimaxillary orthognathic surgery in Class III patients. J Orofac Orthop. 2016;77:400-8.

42. Kim K-A, Chang Y-J, Lee S-H, An H-J, Park K-H. Threedimensional soft tissue changes according to skeletal changes after mandibular setback surgery by using cone-beam computed tomography and a structured light scanner. Prog Orthod. 2019;20:25.
Yazışma Adresi:

Gökhan ÇOBAN

Erciyes Üniversitesi

Diş Hekimliği Fakültesi

Ortodonti AD.

Kayseri, Türkiye

E Posta: dtgokhancoban@hotmail.com 